Article

\title{
Buddhist Mind and Matter
}

\section{Francisca Cho}

Theology Department, Georgetown University, Box 571135, Washington D.C. 20057-1135, USA;

E-Mail: chof@georgetown.edu

Received: 3 March 2014; in revised form: 2 April 2014 / Accepted: 10 April 2014 /

Published: 16 April 2014

\begin{abstract}
Classic Buddhist thought understands the mind as arising in dependence on the body. This causal dependence may be fashioned as a kind of "Buddhist materialism". However, this should not be confused with any variety of scientific materialism, in which ontological and/or causal reductions of mind to brain affirm matter as the fundamental entity or property. Buddhist materialism, in contrast, is a purely phenomenological description that rejects both "mind" and "matter" as entities possessing substance or essential natures. This view questions the presumption that matter is external, real, and scientifically accessible, whereas mind is internal, subjective, and harder to empirically observe. Instead, perceptions of mind and matter are understood to be different kinds of experiences of equal phenomenological reality.
\end{abstract}

Keywords: Buddhism; science; materialism; mind; body; phenomenology

\section{Introduction: Buddhism and the Study of Consciousness}

Buddhism is often looked upon to defend the reality of mind and consciousness from the reductions of scientific materialism. The current Dalai Lama-perhaps the most eloquent and influential spokesman for what Buddhism has to offer science - makes an observation that is compelling to many: "Given that one of the primary characteristics of consciousness is its subjective and experiential nature, any systematic study of it must adopt a method that will give access to the dimensions of subjectivity and experience" ([1], p. 134). Some suggest that Buddhism's long tradition of introspection on mental states offers empirical observations of subjectivity that can be replicated and practiced by others [2,3]. Furthermore, it is suggested that scientists can test and verify the higher states of consciousness described by Buddhism, and their resulting paranormal phenomena, such as recall of former lives $[4,5]$. 
Appeals for non-reductive scientific studies of consciousness can reinforce a strong cultural assumption, however. To wit, they reinforce the conceit that the physical world, in contrast to the mental one, is a given entity that is much easier to access. It is assumed that matter is "out there" for all to observe, unlike someone's consciousness, which is internal and difficult to empirically see. This is why the study of consciousness qua consciousness, rather than as the brain, is approached in the manner of an apology. The thesis of this paper is that a Buddhist contribution to the study of consciousness might be to turn this situation on its head. The Buddhist tradition of phenomenological observation has led it to note that all categories - including matter-are ultimately internal rather than external to consciousness. This tempers the idea that the physical world is plainly "out there" for all to see with the observation that the dualism of "inner" and "outer" worlds is itself a mental discrimination and experience. The result of this observation is not philosophical mentalism, or some assertion that mind is the only thing that exists. On the contrary, Buddhist thought exhibits its own brand of "materialism", which confirms that consciousness is rooted in and dependent upon the body. But just as it rejects the idea of a soul-entity, Buddhist materialism does not treat matter like an ontologically real substance. Instead, matter is one kind of phenomenological event, which is to say, a way in which things appear to us in experience ${ }^{1}$.

The benefits of exploring and understanding this Buddhist materialism are two-fold. First, it offers a new and non-reductionist paradigm for using the language of "mind" and "matter". When scientists and philosophers deploy such language, the default western philosophical framework encourages a view of matter in terms of a substance-essence ontology. Although substance dualism is now commonly rejected in favor of "property dualism," the logical and explanatory dilemmas both create are essentially the same ${ }^{2}$. Buddhist discussions of matter, in contrast, understand it as a range of sensory experiences rather than as a constitutive substance or causal force. This avoids matter-only reductionism and remains consistent with the doctrine of anātman, which not only rejects a soul-substance but a substance and essence behind all "things".

Second, the Buddhist materialism I articulate here helps to clarify common misunderstandings of Buddhism. Buddhism is often described as consonant with science because it rejects the idea of a soul. This sometimes leads people to mistake Buddhism for a form of matter monism. The biologist David Barash, for example, thinks Buddhism agrees "that dualism is nonsense - [and] our minds are nothing but the result of mechanical processes occurring within our brains" ([7], p. 31). Such confusions need to be eliminated. On the other hand, the Buddhist emphasis on the importance of the mind lead others to conclude that Buddhism is a form of dualism that asserts a "spooky" and non-naturalistic form of causation. This too is confused. Buddhist views confirm neither a monist or dualist view of the

1 My use of the term "phenomenology" should not be conflated with its use in the philosophy of mind to mean how the neural substrate of the brain gives rise to mental states. My use derives from classical philosophical phenomenology, with its emphasis on first-person experience, intentionality, and the broader contexts that enable them.

2 As John Searle notes, the property dualist cannot help lapsing into substance dualism ([6], p. 63). The property dualist rejects the existence of ontological substances in favor of distinct material and mental "phenomena". This appears to coincide with how Buddhists talk about mind and matter as qualitatively different experiences. But the property dualist talks about "two mutually exclusive metaphysical categories that constitute all of empirical reality" ([6], p. 58), which has the same philosophical problem as substance dualism: How can two distinct "things", whether substance or property, interact and co-exist? As we will see, this problem does not arise in the Buddhist understanding of mind and matter. 
mind-body complex. Instead, they operate entirely outside the long shadow cast by Cartesianism. Buddhist thought functions with an entirely different paradigm and thereby calls attention to a different way that one might understand modern scientific discussions of matter.

\section{Buddhist Materialism}

The Buddhist view that consciousness (vijñāna) arises from and refers to the sensations and perceptions rooted in the body can be styled — for the present purposes — as a kind of materialism. The Buddhist analysis of the person is materialistic because it begins with the body and rejects postulations of unobservable entities like the "soul".

The Buddhist concept of matter centers on "rūpa", which is normally translated as "form" or "body". Here is a typical discussion from the Pāli Nikāyas of the Theravāda school:

This my body is material, made up from the four great elements, born of mother and father, fed on rice and gruel, impermanent, liable to be injured and abraded, broken and destroyed, and this is my consciousness which is bound to it and dependent on it ([8], I. 76).

The materiality of rūpa is described by the idea that it is made up of the "four great elements," which are earth, water, fire, and wind. In order to understand what these elements mean, we must look first at the pre-Buddhist Indian idea (shared by the Greeks) that the universe is made of limited and unchanging substances that combine and recombine to produce apparent changes in the empirical realm ([9], pp. 300-10). The Indians and Greeks enumerate the exact same four elements, frequently augmented by the fifth element of ether (Sanskrit: ākāśa; Greek: aither). The Indian Vedas alternatively offer fire, water and breath as the ultimate principle of things. In parallel fashion, the Greek cosmologist Thales (ca. 620-546 BCE) proposed water as the ultimate principle (arche) or originative substance, Anaximenes (ca. 528 BCE) postulated air, and Heraclitus (ca. 500 BCE) looked to fire as the determining element. The Indian Upanișads organize the elements into a sequence of solidification or condensation, beginning with air, which leads to fire, then water, and then earth. The Taittiriya Upanișad (2.1) adds plants, food, and finally, persons, to the original four, clearly suggesting a process of creation that culminates in human existence. On the Greek side, it is Empedocles (ca. 492-32 $\mathrm{BCE}$ ) who fully articulates the elements as the four "roots" of things, in contrast to his predecessors, who argued for a single principle. Although the concept of successive condensation and rarefaction is also present in Greek elemental theory, Empedocles follows Parmenides (ca. 510 BCE) in his insistence that each element is ungenerated, indestructible, and unchanging. The combining and recombining of the elements (rather than their conversion from one to the other) accounts for the diversity and changes detected by sensory experience. Hence the elements function as a bridge between the absolute stasis of Being and the dynamism of the phenomenal world.

Elemental theory is generally materialistic in proposing that the elements alone are real and that all things derive from them. The Buddha noticed that this kind of materialism is inevitably tied to troubling ethical worldviews. The Pāli Nikāyas describe the beliefs of various materialist philosophers. The Sāmañ̃aphala Sutta ([8], I. 47-86) describes one Purāna Kassapa who teaches that: 
If one were to go along the south bank of the Ganges killing, slaying, cutting.... there would be no evil as a result of that, no evil would accrue. Or if one were to go along the north bank of the Ganges giving [and] sacrificing.... there would be no merit as a result of that, no merit would accrue ([8], I. 52).

There is also Ajita Kesakambalī of the Cārvāka school who teaches that:

This human being is composed of the four great elements, and when one dies the earth part reverts to earth, the water part to water, the fire part to fire, the air part to air, and the faculties pass away into space.... Fools and wise, at the breaking up of the body, are destroyed and perish, they do not exist after death ([8], I. 55).

And there is Pakudha Kaccāyana, who lists seven things that are "stable as a column" because they ungenerated and indestructible:

The earth-body, the water-body, the fire-body, the air-body, pleasure and pain and the life-principle.... Thus there is neither slain nor slayer, neither hearer nor proclaimer, neither knower nor causer of knowing. And whosoever cuts off a man's head with a sharp sword does not deprive anyone of life, he just inserts the blade in the intervening space between these seven bodies ([8], I. 56).

As one scholar sums it up, "the first [doctrine] exhausts itself in mere denial of all moral obligations. The second seeks to prove it with a gross materialism. The third finally represents an ancient Nature-philosophy which explains all occurrences through the inter-play of a number of permanent factors"- that is, the elements ([10], p. 220). In such views, the Buddhist doctrine of karma, or moral consequence, is denied because life, soul, and consciousness are thought to be temporary products of the elements that perish upon death. The Ājīvikas, led by Makkhali Gosāla, claimed that the elements obey their own laws, influenced neither by gods nor human will, and thus espoused determinism. Aside from the denial of moral consequences and responsibility, life itself is understood as an illusory by-product that technically cannot be wronged or killed because living beings are ultimately nothing but elemental matter.

The interesting question, then, is how the Buddha can employ the notion of material elements without succumbing to an ontology of eternal substances and the philosophy of determinism. The short answer is that when Buddhists talk about "matter," the word does not refer to a substance but rather to a quality of experience. Rūpa, which is the first of the five "aggregates" (skandhas) that comprise the person, is often described as the only material component in the Buddhist mind-body (nāma-rūpa) framework. But this "materiality" has a distinct sense. The later Abhidharma texts "frequently replace the term rūpa with the term phassa (S. sparśa), or "contact", meaning that materiality could be reduced to considerations of how the four namic (mental) skandhas experienced and appropriated it" ([11], p. 160). Hence rūpa does not refer to matter, per se, but to how the mind experiences materiality. This is made clearer by the idea of the second aggregate, sensation/feeling (vedanā), which arises when the sensory faculties make contact with their corresponding objects. Vedanā depends on and results from bodily sense organs, and for that reason would seem to be a material phenomenon as well. But Pāli sources observe that as soon as a physical sensation occurs, our minds immediately brand it as a pleasant, unpleasant, or neutral experience, varnishing the raw sensation with mentally formulated categories ([12], 
IV. 204-50). The term "vedanā", which is commonly translated as "sensation", also has the meaning of "feeling", which blurs the separation between physical and mental functions ([13], pp. 45-46). Interestingly, this point is reinforced by neuroscientific accounts of how the brain represents the world:

Information is extracted, augmented, integrated, and generally worked so that the perceptual product we are aware of, such as the smell of a wet dog, is really a far cry from the peripheral signals. The brain is not a passive reflector of external stimuli; it is in various ways an active constructor that builds the animal's perceptual-motor world ([14], p. 279).

We therefore do not just register tactile sensations, for example. Instead, we feel bumps, jabs, slaps, scratches, caresses, squeezes, crashes - that is, sensations defined by the intentions and emotional content that these words imply. Similarly, there is no such thing as plain and simple visual sensations. Everything we see is some variation of the beautiful, the ugly, the boring, the mouth-watering, the frightening, the heart-warming, the arousing, and so on. In this manner, the mind determines our bodily experiences because sensory objects are always filtered through the interpretive mechanism of the mind. Conversely, matter is an "object" only in the sense that the experience of materiality is an object of mental interpretations rather than a thing in itself. We see clearly here how Buddhist analysis is focused on the process and nature of our experiences rather then the substances of which they are made.

Given this non-literalizing understanding of rūpa, then, what do the Pāli texts mean by declaring that the body is made of the four elements? Buddhist discourse generally accepts the atomistic idea of fundamental entities that cannot be further broken down, and the Abhidharma literature speaks of the four elements as the fundamental components ("dharmas") of material experience. Later Mahāyāna Buddhists criticize this atomism and its implied realism, but in their sectarianism they tend to exaggerate and distort the Abhidharma view. The Sārvastivada Abhidharma, in any case, makes clear that all dharmas, including the material ones, are to be understood as intrinsic characteristics that are phenomenologically cognized, and that this constitutes their reality: "This is no doubt they are quite in keeping with the fundamental Buddhist stance which consistently rejects any substance-attribute dichotomy" ([15], p. 19). In the Abhidharma system, dharmas are made to account for the cognition of differences between our experiences. Consequently, "These (dharmas) do not represent unchanging substrates possessing specific attributes, since dharmas are 'relational notions', not substances” ([16], p. 53).

The Theravāda Abhidharma speaks of the four elements not as "things" but as the most basic aspects and qualities of our experience of materiality. To wit, "earth" is the quality of solidity and extension, "water" that of fluidity and cohesion, "fire" that of cold and heat, and "wind" that of distension and mobility ([17], p. 14; [18], p. 5). "Earth", "water", "fire" and "wind" are not substances, then, but rather a catalogue of the basic ways our minds discriminate between experiences. This experiential sense of the elements is present in more nascent form in the Nikāyas, where they are used to distinguish attributes of physical phenomena, signifying not only parts of the body that are solid or watery, for example, but bodily processes like respiration, which is associated with wind; and digestion, which is associated with heat ([19], I. 186-89). Overall, it is made quite clear that "the notion of 'matter' is purely conventional.... rūpa refers to the occurrence of various states or processes, collectively referred to as the 'body'." ([18], p. 5).

After invoking the four great elements, the Buddha observes that the body is dependently arisen: the materiality of the body is the result of prior and sustaining causes, such as parents and food. Aside 
from sensation/feeling, the remaining skandhas are perception (samjñā), which is the act of discriminating and labeling our experiences; disposition (samskāra), which is our conditioned responses formed by past history and actions; and consciousness (vijñāna), or the act of awareness that is necessary to experience anything at all. In brahminical philosophy, consciousness is associated with Brahman, the eternal stuff of existence (Brhadāranyaka Upanișad 3.9.28). In the Buddhist conception, however, consciousness functions integrally with the senses as awareness of sensory experiences ${ }^{3}$. The mind contributes the attention and awareness that is necessary to hear the bird singing outside your window, which you would not notice if you were absorbed in reading a book or daydreaming. Hence the participation of the mind is necessary in order to experience materiality. The Nikāyas make this clear in stating that the sense faculties alone cannot produce sensory experience: "If internally the ear is intact and external forms come into its range, but there is no corresponding [conscious] engagement, then there is no manifestation of the corresponding class of consciousness" ([19], I. 190). The participation of the mind is necessary for sensory experience to occur, and consciousness is usually consciousness of something - the sound of a bird, the smell of flowers, the sensation of clothes against skin, as well as thoughts. Our bodies may be bombarded with sensory stimuli, but only mind enables us to have conscious experience of them.

In a manner of speaking, then, Buddhism affirms that consciousness arises in dependence on the body and physical processes. But this "dependency" does not mean that mind is reduced to matter. Rather, it means that consciousness requires the body as a primary object of its functions, and, quite importantly, the body also needs the mind to complete its own sensory processes. The metaphor of two sheaves of reeds illustrates this idea: "Just as two sheaves of reeds might stand leaning against each other, so too, with name-and-form as condition, consciousness [comes to be]; with consciousness as condition, name-and-form [comes to be]" ([12], II. 114). "Dependency" here means a mutual process of causation rather than the reduction of one purported "thing" into the other. In the Visuddhimagga ("Path of Purification"), Buddhaghoșa (4th-5th century) likens this dependency to the relationship between a blind man and a cripple: On their own they are each impotent, but when the cripple sits on the blind man's shoulders, they can become a functional unit.

So too, mentality has no efficient power; it does not arise or occur in such and such functions by its own efficient power. And materiality has no efficient power, it does not arise or occur in such and such functions by its own efficient power. But there is nothing to prevent their occurrence when they support each other ([20], p. 691).

This view of mind and body as mutually supporting events differs significantly from the Cartesian assertion that mind and body are mutually exclusive substances. Paul Griffiths observes that "Buddhist intellectuals were not, when discussing the mind-body problem, considering the possible relations between qualitatively different substances" ([21], p. 108). This led to the conclusion that "certain kinds of causal interaction between the mental and the physical are envisaged, but no event of one class can ever come into existence solely as the result of the occurrence of an event of another class" ([21], p. 112). In other words, mind and body interact because of the very fact that they do not comprise ontologically

3 This is why the mind is recognized as the sixth sensory organ in Buddhism. Mental awareness and attention are necessary to have visual consciousness, aural consciousness, and so forth. This also emphasizes that physical sensory experiences are fundamentally events-in-consciousness, as opposed to things that can be separated from consciousness. 
different substances. Furthermore, neither one can be posited as the sole cause of the other. The Buddhist picture of mind and body is neither dualistic nor monistic, but rather phenomenological in recognizing them as two qualitatively different kinds of experiences.

\section{Mental Causality}

In the current engagement with science, Buddhists like the Dalai Lama point to the classic Buddhist distinction between mind and body in order to renounce matter reductionism: "From the Buddhist perspective, the mental realm cannot be reduced to the world of matter, though it may depend upon that world to function" ([1], p. 126). The legacy of Cartesianism in western philosophy encourages misconstruals of the priority that Buddhists give to the mind over the physical world. We can take the notion of karmic causality as an illustrative example. Buddhists believe that mental acts have the power to create consequences that are physical in nature - such as the forms of rebirth, or natural events that are visited upon people as a result of their karma (mental action). Owen Flanagan takes this notion of mental causation to mean that Buddhists believe in "an ontologically unique kind of causation" in which "immaterial properties of sentient beings produce causal effects in the natural world" ([22], p. 78). Flanagan reads karma theory squarely through the lenses of the western mind-body problem, and concludes that karma doctrine must be an assertion of an ontologically unique mind-stuff.

This mistakes western philosophical frameworks for Buddhist ones, and ignores the specific religious goal driving the Buddhist view of mind. The purpose of Buddhist observations of human experience is to alleviate suffering, particularly the kinds created by mental delusions and distortions. The desire to correct such afflictions leads to the Buddhist emphasis on the mental life: "Since the actualization of value and meaning in our lives very much depend on the quality of the psyche, the spiritual aspect of human existence is valued equally, if not more highly than the material aspects" ([23], p. 254). Consequently, it is important to Buddhists to address the mind at the level of mental phenomena, because it is mental processes that determine the way humans see and experience the world around them. The fact that brain structure, evolution, and pathology affects mental experience makes neuroscience highly relevant to Buddhist practice, as the Dalai Lama's interest in it confirms. But this reinforces rather than demotes the priority of mental experience over the brain, per se.

This value system is foundational to the Buddhist notion of karmic causality. Karma, which means "action", is thought to be more mental than physical when it comes to determining immediate and future consequences. This includes the provision that mental acts can cause physical consequences, such as the manner in which one's own body evolves, and the occurrence of natural events that are "rewards" or "punishments" for prior mental acts. In terms of modern science, the first claim has perhaps become more acceptable: Studies confirm the impact of mental attitudes and states on physical health through mechanisms such as stress hormones, and mental volition clearly shapes habits - such as diet and exercise - that determine our physical condition. But when it comes to the idea that human mental acts can determine events in the external natural world, it appears that we are in the realm of supernatural causality.

Understanding the mechanics of karmic consequence has been a philosophical problem for Buddhists themselves. Johannes Bronkhorst sums up the general nature of the conundrum: "How should we imagine that the series of mind-events that constitute animate beings determine what 
happens outside them in the material world?" ([24], p. 81). The question has been particularly challenging for Buddhists because they do not turn to an intelligent and divine agent as an explanation. The resulting puzzles are many, tracking the diverse ways in which "natural events" can be defined. For example, how and why does some karma mature as consequences within the same lifetime and some much later in subsequent lives? How do karmic consequences trail an individual when persons themselves comprise nothing but momentary and constituent events with no enduring substance? Also, since karma operates in peoples' interactions with each other as well as with their natural environment, how can we determine whose karma is responsible for which aspect of the shared experience?

Such interpretive puzzles were increased rather than settled by canonical sources. For example, the Buddha denies that every pleasant or unpleasant event can be attributed to past karma. Sometimes, he says, unpleasant feelings arise due to bile and phlegm disorders, a change in climate, simple carelessness, or through the fault of others. The explanation of things are often close at hand, he cautions, and we should not overshoot the mark by constantly invoking karma ([12], IV. 230-31). It is interesting that the Buddha appeals to common sense empirical explanations here. But then how do we know when an event is the result of purely natural causes or the consequence of one's personal karma? The idea of karmic retribution raises numerous interpretive difficulties that the Buddhist tradition has not clearly resolved. But the very existence of this predicament strongly indicates that Buddhists do not see consciousness as an ontological force or entity capable of operating on its own powers. If they did so, then the aforementioned interpretive problems would not arise.

We can gain further clarity by looking at the solution of one prominent Buddhist philosopher, Vasubandhu (4th century), the great systematizer of Abhidharma thought and proponent of the Mahāyāna Yogācāra school. His conclusion is that all karmic retribution is ultimately mental, in the sense that mental dispositions determine how people interpret the events that happen to them. "Why is a transformation of consciousness itself due to (past) actions not accepted, and why instead are material elements constructed?" he asks ${ }^{4}$. In other words, we need not see the mind as the cause of physical events in the world. Instead, past mental states give rise to present ones, which in turn give meaning to external events. Impressions through actions create a consciousness-series, Vasubandhu explains, and its effect should be "accepted as being such a transformation of consciousness taking place just where the impressions themselves do" ([25], pp. 164-65). To see the tornado that destroyed your house as the result of bad karma is itself an act of mind upon the mind, not upon the physical world. A different consciousness-series might see the explanation for the tornado closer at hand, such as in the physics of air molecules.

As an exponent of Yogācāra "perception-only" (vijñapti-mātra) phenomenology, Vasubandhu believes that mental images can be created without dependence on external objects. The "perception-only" pronouncement declares that what we perceive as external objects are caused by transformations in consciousness: "This transformation of consciousness is a discrimination, and as it is discriminated, it does not exist, and so everything is perception-only" ([26], p. 187). In terms of karmic retribution, this

4 To be clear, in this passage Vasubandhu is arguing against the idea that hell (which Buddhist texts describe in gory detail) are actual physical places into which people are reborn as a result of bad karma. He claims instead that hell is an internal object of consciousness, created by a prior series of consciousness states. I modify Vasubandhu's argument here so that the perception of "external" events such as punishing tornados are also internal consciousness-objects. 
confirms again that the perception of an external world is always fundamentally a mental event ${ }^{5}$. This does not mean that mind is the ultimate reality in the sense of an ontological substance or force. What "exists" is simply the flow of dependently arising perceptions, which are then conceptualized into external worldly "objects" and internal perceiving "subjects". Unenlightened beings take these discriminated subjects and objects to be real, and "As long as consciousness is not situated within perception-only, the residues of a 'dual' apprehension will not come to an end" ([26], p. 189). In our current society, the dichotomy of subject and object forms the axiomatic framework of thought, in spite of variations in the details. Both halves of this construction of really-existing-subjects confronting really-existing-objects are forms of mental discrimination that have no independent reality, according to Yogācāra. There are no actual subjects or objects but only the flow of dependently arising perceptions.

What separates Buddhist thought from science is not its preference for mind over matter. The real difference is that Buddhism prioritizes the phenomenology of experience. The doctrine of karma focuses on "how certain kinds of mentality that condition the ways in which one thinks, talks and behaves, shape and determine one's course of life and one's relation to the environment” ([27], p. 200). The character of our mental acts conditions and leads to corresponding outward acts, which in turn create a social environment. A person who has cultivated a loving disposition naturally engages in acts of loving kindness, eliciting responses in kind from other people. Buddhist causality has a moral orientation and message: compassion breeds compassion, hatred breeds hatred, and most of all, ignorance breeds suffering. This process includes and entails the physical world, for our experience of the natural environment is also determined by our intentionality, which acts on the environment in turn.

Flanagan insists that understanding these kinds of things "can be done inside the framework of scientific materialism" ([22], p. 78). But for Flanagan, such materialism requires rejecting all talk of mind in its own terms. So when the Dalai Lama says that the "essential luminous nature of awareness" is not physical or parsable in terms of neural correlates [28], Flanagan automatically reads this in terms of the monist versus dualist metaphysical debate. He retorts, "Scientists will say that there is no evidence that 'pure luminous consciousness', assuming it exists at all, is immaterial, and that it is an inference to the best explanation that it is realized in the brain" ([22], p. 86). Again, this misses the point of Buddhist thought. In Buddhist philosophy, the innate purity of mind is an important concept because it asserts the potential of all beings to attain enlightenment ${ }^{6}$. It affirms that greed, hatred, and ignorance are not intrinsic to who we are and that self-transformation is possible. This idea goes hand-in-hand with the Buddhist rejection of substantialism, which is to say that humans are not made of stuff with intrinsic essences. Instead, they are dependently arising events that are always in process and which therefore can change. In overt contrast to Flanagan's imposition of mind-stuff ontology,

5 There is an active debate among Yogācāra scholars as to whether or not "perception-only" means that external objects do not exist at all. In referring to external objects here, I do not necessarily take sides in this debate but rather make a point with which all sides agree: Even if there are external objects in the world, they are cognized as objects of consciousness rather than in themselves.

6 The concept of "Buddha-nature" which begins in India and has a dominant presence in East Asian Buddhism is sometimes accused of introducing a metaphysical "self" or "mind" by rival Buddhist schools, as well as by contemporary scholars. I side with the indigenous sources that deny the charge. The debate about Buddha-nature is essentially soteriological, regarding the possibility of all beings to attain liberation. The Mahāyāna dominated cultures of East Asia and Tibet affirm this possibility. 
Buddhist assertions about the pure "original nature" and "original mind" of human beings explicitly reject the idea of any kind of innate qualities.

\section{The Karma of Science}

The so-called "mind-body problem" in western philosophy and science is a perfect example of karmic causality - that is, a mental event that actively fosters an external reality. Constituting the mind and body as mutually exclusive properties is a mental act and choice, made evident by the fact that not all cultures - such as Buddhist ones - make the same assumption. Furthermore, the assumption leads directly to actions that create institutional realities and practices in the realm of science. Naturalists are vigilant against "improper" or "unempirical" talk about consciousness because of what they believe to be at stake:

If consciousness can be sensibly thought of as part of the natural fabric of the universe, then we are able to avoid positing ontologically queer substances or properties, and in addition the science of mind can proceed with the hope that understanding mind and mental causation is possible ([22], p. 84).

In other words, the scientific investigation of consciousness depends on the elimination of queer properties beyond the reach of scientific methods of investigation. So within this framework, operationalizing the mind into brain states is necessary. To see mind as something other than matter is to render it "a semimagical glow emanating from the soul or permeating spooky stuff" ([14], p. 2). Because of the prior mental framing, scientists are forced to declare that no "wonder tissues" are allowed, nor appeals to "inexplicable or unknown forces, substances, or organic powers" ([29], p. 40).

What tends to be forgotten in this institutional and cultural battle, however, is how the problem itself has been called into existence by mental acts. After the mental constructs of "mind" and "body" are asserted, logic dictates that if they refer to two different kinds of things, then it is impossible for the mind, which is immaterial, to act upon the body, which is material. As Flanagan states,

The view that immaterial stuff or properties can cause anything to happen is an idea, which despite numerous noble efforts no one has ever been able to make sense of. The idea that it is possible is inconsistent with all known scientific law ([30], p. 92).

Logically speaking, if the mind is a physical "nothing" in contrast to the physical "something" of the body, then we have the intractable question of how a "something" and a "nothing" can ever interact-or the "mind-body problem". Current philosophers reject both substance and property dualism on the grounds that the mind clearly exerts causal force upon matter. John Searle states, "it is just a plain fact about how the world works that our conscious mental states function causally in the production of our behavior" ([31], p. 62). Owen Flanagan agrees that epiphenomenalism, or the view that consciousness does no causal work, is unacceptable. He notes, "I decide to go to the movies and I [actually] go" ([22], p. 88). But their subsequent accounts of consciousness do not deviate from standard matter-centered monism. Searle, for example, explains that while consciousness is real, it is simply a function of the brain, just as digestion is a function of the stomach ([6], p. 60). In this, Searle differs from materialists who deny the reality of inner consciousness states altogether. He in fact affirms that mind cannot be ontologically reduced to matter, but that it can be causally reduced ([6], p. 62). 
So he concludes that consciousness is a feature of the brain, contra the dualist who insists that it is something over and above the brain. But Searle's causal reductionism has the same problem as substance monism - to wit, how does brain-matter give rise to the qualitatively different phenomenon of consciousness? In the words of David Chalmers, "It is widely agreed that experience arises from a physical basis, but we have no good explanation of why and how it so arises. Why should physical processing give rise to a rich inner life at all? It seems objectively unreasonable that it should, and yet it does" ([32], p. 202). Chalmers calls this the "hard problem" of consciousness ${ }^{7}$.

The reason why the "mind-body problem" and the "hard problem of consciousness" exist at all is because the words "matter" and "consciousness" are treated as if they refer to self-existing properties, forces, or substances. The fundamental question, however, is why one needs to talk about "stuff" at all, spooky or material. Buddhist empirical analysis is not a description of the external world, but rather an account of events as perceived by our sensory apparatus, which most importantly includes the mind. The Yogācāra claim of "perception-only" (vijñapti-mātra) or "mind-only" (citta-mātra) has the "intent of laying out an indictment of the problems that the activities of consciousness engender" ([11], p. 435). A distinctive feature of the mental process is that it externalizes consciousness-events into objects, as if they exist independently of consciousness-acts. This movement from subjective experience to objective "thing-ness" is how the mind patterns knowledge, and this is particularly so when it comes to the body: "'Rūpa' is, then, a cognitive reversal-seeing what is of consciousness as something external to consciousness. It makes experience a place in which cognitive objects can be grasped, taken, pointed at, referred to and seized" ([11], p. 479).

In contrast to this act of grasping, we can see "matter" as a highly useful and necessary word when it comes to analyzing our experiences, as Buddhist discourse itself confirms. Mental discriminations, with their selective foci, are necessary to human survival and activity. The distinction between mind and matter exemplifies just this kind of productive human schema. It is an example of the way we humans organize our experiential processes and the relationships between them, to address aspects of our existence that are important to us. To use the word "matter" productively means being constantly aware that the term exists for our own use, and what we do with it is what gives "matter" its most important reality. This is an alternative understanding of what science also does, and what "materialism" might entail. This means practicing science without the ontological scaffolding bequeathed by Greek philosophy and to understand "matter" purely as a phenomenological term.

\section{Conflicts of Interest}

The author declares no conflict of interest.

\footnotetext{
Searle admits, "we really do not understand how brain processes cause consciousness" and states that the traditional vocabulary that contrasts the mental and the physical is "confused and obsolete" ([6], p. 57). His own attempt to get beyond this vocabularly, however, amounts to his distinction between causal and ontological reductionism. But if property dualism is really no different from substance dualism, as Searle correctly observes, then his own favoring of causal over ontological reductionism is no more successful in substantially departing from the traditional distinction between mind and matter.
} 


\section{References}

1. Gyatso, Tendzin. The Universe in a Single Atom. New York: Morgan Road Books, 2005.

2. Wallace, B. Allan. The Taboo of Subjectivity: Toward a New Science of Consciousness. New York: Oxford University Press, 2000.

3. Wallace, B. Allan. Contemplative Science: Where Buddhism and Neuroscience Converge. New York: Columbian University Press, 2007.

4. Stevenson, Ian. Children Who Remember Past Lives: A Question of Reincarnation. Jefferson, North Carolina: McFarland \& Company Inc., 2000.

5. Tucker, Jim B. Life Before Life: Children's Memories of Previous Lives. New York: St. Martin's Griffin, 2008.

6. Searle, John R. "Why I am Not a Property Dualist." Journal of Consciousness Studies 9, no. 12 (2002): 57-64.

7. Barash, David. Buddhist Biology: Ancient Eastern Wisdom Meets Modern Western Science. New York: Oxford University Press, 2014.

8. Walshe, Maurice, trans. Dīgha Nikāya (The Long Discourses of the Buddha). Somerville: Wisdom Publications, 1995.

9. McEvilley, Thomas. The Shape of Ancient Thought: Comparative Studies in Greek and Indian Philosophies. New York: Allsworth Press, 2002.

10. Frauwallner, Erich. History of Indian Philosophy. Delhi: Motilal Banarsidass, 1973, vol. 2.

11. Lusthaus, Dan. Buddhist Phenomenology: A Philosophical Investigation of Yogacara Buddhism and the Ch'eng Wei-shih lun. London: RoutledgeCurzon, 2002.

12. Bodhi, Bhikkhu, trans. Samyutta Nikāya (The Connected Discourses of the Buddha). Somerville: Wisdom Publications, 2000.

13. Hamilton, Sue. Early Buddhism: A New Approach. The I of the Beholder. Richmond, Surrey: Curzon, 2000.

14. Churchland, Patricia. Brain-Wise: Studies in Neurophilosophy. Cambridge, MA: Massachusetts Institute of Technology, 2002.

15. Dhammajoti, Bhikkhu KL. Sarvāstivāda Abhidharma. Hong Kong: Centre of Buddhist Studies, The University of Hong Kong, 2009.

16. Waldron, William S. The Buddhist Unconscious: The Älaya-Vijñanna in the Context of Indian Buddhist Thought. London: RoutledgeCurzon, 2003.

17. Karunadasa, Y. The Buddhist Analysis of Matter. Columbo, Ceylon: Department of Cultural Affairs, 1967.

18. Hamilton, Sue. Identity and Experience. London: Luzac Oriental, 1996.

19. Ñāṇamoli, Bhikkhu, and Bhikkhu Bodhi, trans. Majjhima Nikāya (The Middle Length Discourses of the Buddha). Somerville: Wisdom Publications, 1995.

20. Ñyāṇamoli, Bhikkhu, trans. Visuddhimagga (The Path of Purification). Boston: Shambhala, 1976, vol. $1,2$.

21. Griffiths, Paul. On Being Mindless: Buddhist Meditation and the Mind-Body Problem. La Salle, Illinois: Open Court, 1986. 
22. Flanagan, Owen. The Bodhisattva's Brain: Buddhism Naturalized. Cambridge, MA: MIT Press, 2011.

23. Lin, Chien-Te. "Rethinking Mind-Body Dualism: A Buddhist Take on the Mind-Body Problem." Contemporary Buddhism 14, no. 2 (2013): 239-64.

24. Bronkhorst, Johannes. Karma. Honolulu: University of Hawaii Press, 2011.

25. Anacker, Stefan, trans. "Viṃśatika-kārikā [vrrtti] (The Twenty Verses and Their Commentary)." In Seven Works of Vasubandhu: The Buddhist Psychological Doctor. Delhi: Motilal Banarsidass, 1984.

26. Anacker, Stefan, trans. "Triṃśikā-kārikā (The Thirty Verses)." In Seven Works of Vasubandhu: The Buddhist Psychological Doctor. Delhi: Motilal Banarsidass, 1984.

27. Ronkin, Noa. Early Buddhist Metaphysics: The Making of a Philosophical Tradition. London: RoutledgeCurzon, 2005.

28. Tendzin Gyatso. "Human Nature: On the Luminosity of Being." New Scientist 178, no. 2396 (2003): 42-43.

29. Dennett, Daniel. Consciousness Explained. Boston: Little, Brown and Company, 1991.

30. Flanagan, Owen. The Really Hard Problem: Meaning in a Material World. Cambridge, MA: MIT Press, 2007.

31. Searle, John R. Mind, Language, and Society: Philosophy in the Real World. New York: Basic Books, 1998.

32. Chalmers, David. "Facing Up to the Problem of Consciousness." Journal of Consciousness Studies 2, no. 3 (1995): 200-19.

(C) 2014 by the author; licensee MDPI, Basel, Switzerland. This article is an open access article distributed under the terms and conditions of the Creative Commons Attribution license (http://creativecommons.org/licenses/by/3.0/). 